\title{
Electron Microscopy in Differential Diagnosis of Poxvirus Infections
}

\author{
J. NAGINGTON,* M.D.
}

[With Special Plate]

Brit. med. F., 1964, 2, 1499-1500

In skin infections due to viruses cultural methods for the demonstration of the virus cannot yet be applied to them all and they often suffer from the slowness of growth of the virus. It is usually necessary first to detect the presence of a virus by the cytopathic effect it produces in the tissue-culture cells and then to identify it by neutralization or other tests based on a second set of cultures.

Identification of the virus particles in material direct from the lesion has been found a most useful additional diagnostic method. It not only enables a provisional result to be obtained in a matter of hours but can be applied to infections where the virus either does not grow in the available tissue-culture systems -for example, warts virus-or grows slowly and irregularlyfor example, orf or contagious pustular dermatitis virus (Nagington and Whittle, 1961).

A method which depends on recognition of virus morphology may not be a conclusive means of identification, and it needs confirmation by other means whenever possible. It is most valid where the morphological type is distinct-for example, orf-and is particularly valuable in deciding between two morphologically different alternatives such as herpes simplex and vaccinia or another poxvirus.

Virus infections which have been found especially suitable for this approach include the following:

1. Poxvirus Group.-There are two distinct morphological types. (a) Rectangular, approximately 300 by $250 \mathrm{~m} \mu$ in phosphotungstate contrast preparations (Special Plate, Fig. 1). Includes vaccinia, variola, cowpox (Fenner and Burnet, 1957), and probably the majority of animal poxviruses. Molluscum contagiosum is now classified with the poxvirus group (van Rooyen and Rhodes, 1963) and appears most similar to this morphological type (Banfield and Brindley, 1959). (b) Cylindrical, approximately 260 by $160 \mathrm{~m} \mu$ (Special Plate, Fig. 2). So far only orf (Nagington and Horne, 1962), bovine papular stomatitis (Nagington et al., 1962), and milkers' nodules (Friedman-Kien et al., 1963) or pseudocowpox virus have been found of this type.

2. Herpes Simplex and Varicella.-Morphologically indistinguishable, these are spherical, approximately $100 \mathrm{~m} \mu$ in diameter, with a conspicuous subunit-structure, and the diameter is increased to approximately $200 \mathrm{~m} \mu$ when an outer envelope is present (Wildy et al., 1960 ; Almeida et al., 1962).

3. Warts.-Spherical, approximately $55 \mathrm{~m} \mu$ in diameter (Special Plate, Fig. 3), with a characteristic pattern of subunits (Williams et al., 1961), the number of which is still debated (Melnick, 1962 ; Mattern, 1962).

\section{Specimens}

The most suitable material to examine depends on the type of lesion. Vesicular lesions have been found to yield a considerable amount of virus in the fluid, and techniques are described for varicella by Almeida et al. (1962) and for herpes simplex by Smith and Melnick (1962).

Vesicular fluid in poxvirus lesions is probably best reinforced by scrapings from the base of the vesicle (Bedson et al., 1955).

* Public Jealth Laboratory Service, Cambridge.
Fluid alone was negative when examined by culture and microscopy in two subsequently confirmed orf infections.

Crusts contain a considerable amount of virus due to the concentration produced by drying as the crust forms. Fragments the size of a pin-head have been found to contain an adequate quantity for the method described. As detailed viral morphology appears to be well preserved in crusts they are probably usable after a considerable length of time. Crusts several months old from animal lesions gave excellent orf preparations, and vaccinia crusts 30 days old were equally good.

In the granulomatous stage of orf and warts infections small biopsy specimens also contain a considerable quantity of virus.

No preservative or refrigeration of the specimen is necessary in transit to the laboratory.

\section{Method}

The crust or biopsy material is cut into small fragments and suspended in 1 or $2 \mathrm{ml}$. of $0.004 \mathrm{M} \mathrm{Mcllvaine} \mathrm{buffer} \mathrm{pH} 7.8$ and disrupted at $4^{\circ} \mathrm{C}$. in an MSE 60-watt ultrasonic disintegrator for two and a half minutes at maximum output.

The coarse debris is removed by centrifugation at 3,000 r.p.m. for 20 minutes and the supernatant centrifuged at 20,000 r.p.m. for 20 minutes $(32,000 \mathrm{~g})$ in the SW 39L rotor of a Spinco preparative ultracentrifuge.

The supernatant is removed as completely as possible and the pellet suspended in one drop of distilled water. Two or three dilutions of this suspension are made on a waxed slide with equal droplets of $5 \%$ sodium phosphotungstate $\mathrm{pH} 6.5$. Micro-drops of these dilutions are transferred to carboncoated nitrocellulose films on standard electron-microscope grids and examined at an instrumental magnification of $\times 10,000$. Intensive search has not been found necessary, as there are usually 10-100 virus particles per grid square. The time required for the whole procedure is two to three hours.

\section{Results}

The results obtained from examination of 20 specimens by both electron microscopy and tissue culture are shown in Table I, where it can be seen that microscopy was effective in all 20 but culture failed or was inconclusive in four instances because warts virus does not grow in the cells used, two of the

TABLE I.-Specimens Examined by Electron Microscopy and Tissue Culture

\begin{tabular}{|c|c|c|c|c|c|c|c|}
\hline \multirow{2}{*}{\multicolumn{2}{|c|}{ Virus }} & \multirow{2}{*}{\multicolumn{2}{|c|}{$\begin{array}{c}\text { Material } \\
\text { Examined }\end{array}$}} & \multirow{2}{*}{ Total } & \multicolumn{2}{|c|}{ Positive Results } & \multirow{2}{*}{$\begin{array}{c}\text { C.P.E. } \\
\text { not } \\
\text { Trans- } \\
\text { missible }\end{array}$} \\
\hline & & & & & $\begin{array}{c}\text { Electron } \\
\text { Microscopy }\end{array}$ & Culture & \\
\hline $\begin{array}{l}\text { Orf ... } \\
\text { Vaccinia } \\
\text { Warts }\end{array}$ & $\because$ & $\begin{array}{r}10 \\
2 \\
0\end{array}$ & $\begin{array}{l}7 \\
0 \\
1\end{array}$ & $\begin{array}{r}17 \\
2 \\
1\end{array}$ & $\begin{array}{r}17 \\
2 \\
1\end{array}$ & $\begin{array}{c}16 \\
2 \\
0\end{array}$ & $\begin{array}{l}2 \\
0 \\
-\end{array}$ \\
\hline Totals & .. & 12 & 8 & 20 & 20 & 18 & - \\
\hline
\end{tabular}

C.P.E. = Cytopathic effect.

Warts virus does not produce C.P.E. in these tissue-culture systems, which were primary human amnion and secondary monkey kidney.

The material used was from human sources in the case of warts, vaccinia, and 6 
orf strains failed to grow on passage although cytopathic change was produced initially, and a third strain failed to produce any detectable changes in tissue culture.

It should be noted that the minimum times given in Table II for a cultural diagnosis are only the earliest appearance of sufficient cytopathic change to be considered typical enough

TABle II.-Minimum Times Before a Provisional Diagnosis was Possible

\begin{tabular}{|c|c|c|c|c|c|}
\hline \multirow{3}{*}{ Virus } & \multirow{3}{*}{$\begin{array}{c}\text { Electron } \\
\text { Microscopy }\end{array}$} & \multicolumn{4}{|c|}{ Tissue Culture } \\
\hline & & \multirow{2}{*}{ Cells } & \multirow{2}{*}{$\begin{array}{l}\text { Earliest } \\
\begin{array}{l}\text { Mean } \\
\text { Time }\end{array} \\
\end{array}$} & \multicolumn{2}{|c|}{$\begin{array}{l}\text { Characteristic C.P.E. } \\
\text { in Days }\end{array}$} \\
\hline & & & & Range & $\begin{array}{c}\text { No. of } \\
\text { Specimens }\end{array}$ \\
\hline $\begin{array}{l}\text { Orf } \\
\text { Vaccinia }\end{array}$ & $\begin{array}{l}2-3 \text { hours }\{ \\
2-3 \text { hours }\end{array}$ & $\begin{array}{l}\text { Amnion } \\
\text { Bovine testis } \\
\text { Amnion }\end{array}$ & $\begin{array}{l}5 \cdot 3 \\
5 \cdot 2 \\
1.3\end{array}$ & $\begin{array}{l}2-20^{*} \\
2-20 \\
1-3\end{array}$ & $\begin{array}{r}15 \\
99 \\
16\end{array}$ \\
\hline
\end{tabular}
* One specimen, included in Table $I$, is omitted from this series because the range. The vaccinia cultures are taken from a warger series which was unaccompanied by microscopy.

In each case the cells are primary cultures. Bovine testis cultures were prepared as described by Ferris and Plowright (1958).

to warrant a provisional report. This obviously requires confirmation by further observation and subculture accompanied by neutralization or other serological tests.

The application of the technique for differential diagnosis is illustrated by the warts virus specimen. The patient was a farm worker who developed a single granulomatous lesion on the right thumb which was thought to be orf by one clinician and a wart by another.

The shortest time for the examination of a specimen and a positive report was found to be two hours.

\section{Conclusions}

The disadvantages of the electron-microscopic technique are the nature of the apparatus required and the fallacies inherent in any morphological technique. The first can be overcome by sending the specimen to a laboratory where facilities are available. The advantages are its quickness, the differentiation between two distinct viruses, and the identification of virus particles in material from which they cannot be grown.

It could be a valuable extra technique for smallpox diagnosis provided that it is used in conjunction with other methods. Especial care would be necessary to prevent laboratory infec- tions from the aerosol produced during sonication, but a safe method for handling this material should not be difficult to devise.

In view of the degree of resolution demonstrated in Fig. 3 the application of the method to viruses smaller than warts virus should be feasible provided they are present in sufficient quantity.

\section{Summary}

Confirmation of the clinical diagnosis in orf infections is often prolonged by the slow growth of the virus in tissue culture.

To overcome this difficulty a simple preparative technique has been evolved for the recognition of virus particles in the clinical material within a few hours. Crusts or biopsy specimens are broken up by ultrasonic vibration, the virus is concentrated by centrifugation and examined by electron microscopy with phosphotungstate as a contrast agent.

The examination of 20 specimens by this technique in parallel with tissue culture is described. These comprised 17 orf, 2 vaccinia, and 1 wart infection.

The results obtained suggest that the technique might be extended to some other viral skin infections to supplement existing methods.

I am indebted to Dr. George Tee for his help and much of the clinical material.

\section{REFERENCES}

Almeida, J. D., Howatson, A. F., and Williams, M. G. (1962). Virology,

Banfield, W. G., and Brindley, D. C. (1959). Ann. N.Y. Acad. Sci., 81, 145.

Bedson, S. P., Downie, A. W., MacCallum, F. O., and Stuart-Harris, C. H. (1955). Virus and Rickettsial Diseases, 2nd ed., p. 170. Arnold, London.

Fenner, F., and Burnet, F. M. (1957). Virology, 4, 305.

Ferris, R. D., and Plowright, W. (1958). F. Path. Bact., 75, 313.

Friedman-Kien, A. E., Rowe, W. P., and Banfield, W. G. (1963). Science, 140, 1335 .

Mattern, C. F. T. (1962). Ibid., 137, 612.

Mattern, C. F. T. (1962). Ibid., 137, 612.
Melnick, J. L. (1962). Ibid., 135, 1128.

Nagington, J., and Horne, R. W. (1962). Virology, 16, 248

- Plowright, W., and Horne, R. W. (1962). Ibid., 17, 361 and Whittle, C.. H. (1961). Brit. med. $¥$., 2, 1324

van Rooyen, C. E., and Rhodes, A. J. (1963). Virus Diseases of Man, 3rd ed. Nelson, New York.

Smith, K. O., and Melnick, J. L. (1962). Science, 137, 543.

Wildy, P., Russell, W. C., and Horne, R. W. (1960). Virology, 12, 204.

Williams, M. G., Howatson, A. F., and Almeida, J. D. (1961). Nature (Lond.), 189, 895.
Splenoportography has proved extremely valuable in the investigation of patients with portal hypertension, particularly in those where surgical therapy is contemplated, for prior knowledge of the state of the portal and splenic veins enables a planned procedure to be carried out. Splenic puncture, however, always carries a certain risk from haemorrhage, and should never be done if the prothrombin time is more than two seconds prolonged. A serious disadvantage of the

* Consultant Radiologist, Royal Free Hospital, London. t Lecturer in Medicine, Royal Free Hospital, London. method is that occasionally all the contrast medium is diverted into collateral channels and the portal vein is not filled even though it may be patent. Furthermore, patients who have had a previous splenectomy may require investigation. Other techniques for showing the portal vein which can be tried in these patients are not very satisfactory. The retrograde injection of contrast medium through a wedged hepatic-vein catheter (Tori, 1953) or direct transhepatic portography (Bierman, Steinbach, White, and Kelly, 1952) requires a high injection pressure which may damage the liver parenchyma. 


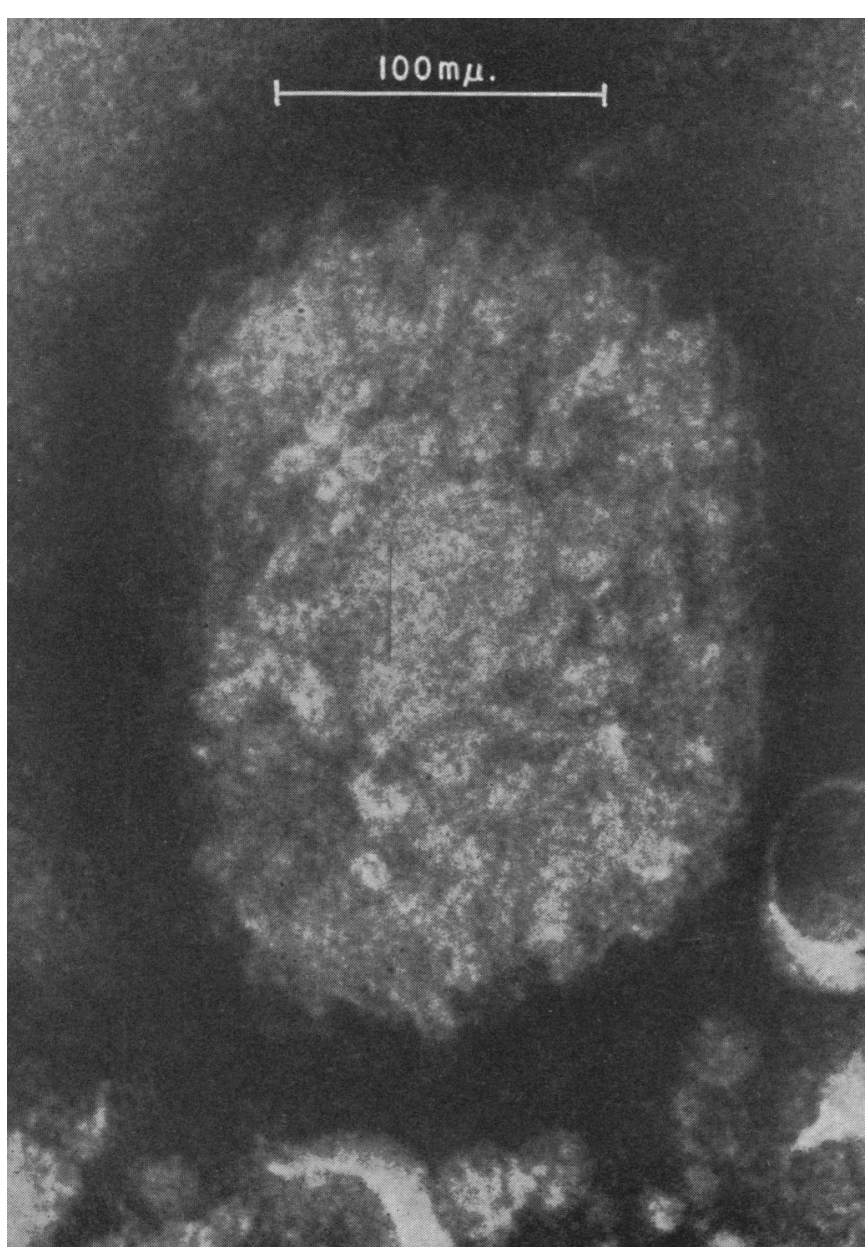

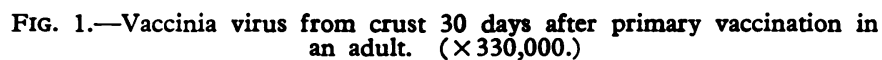

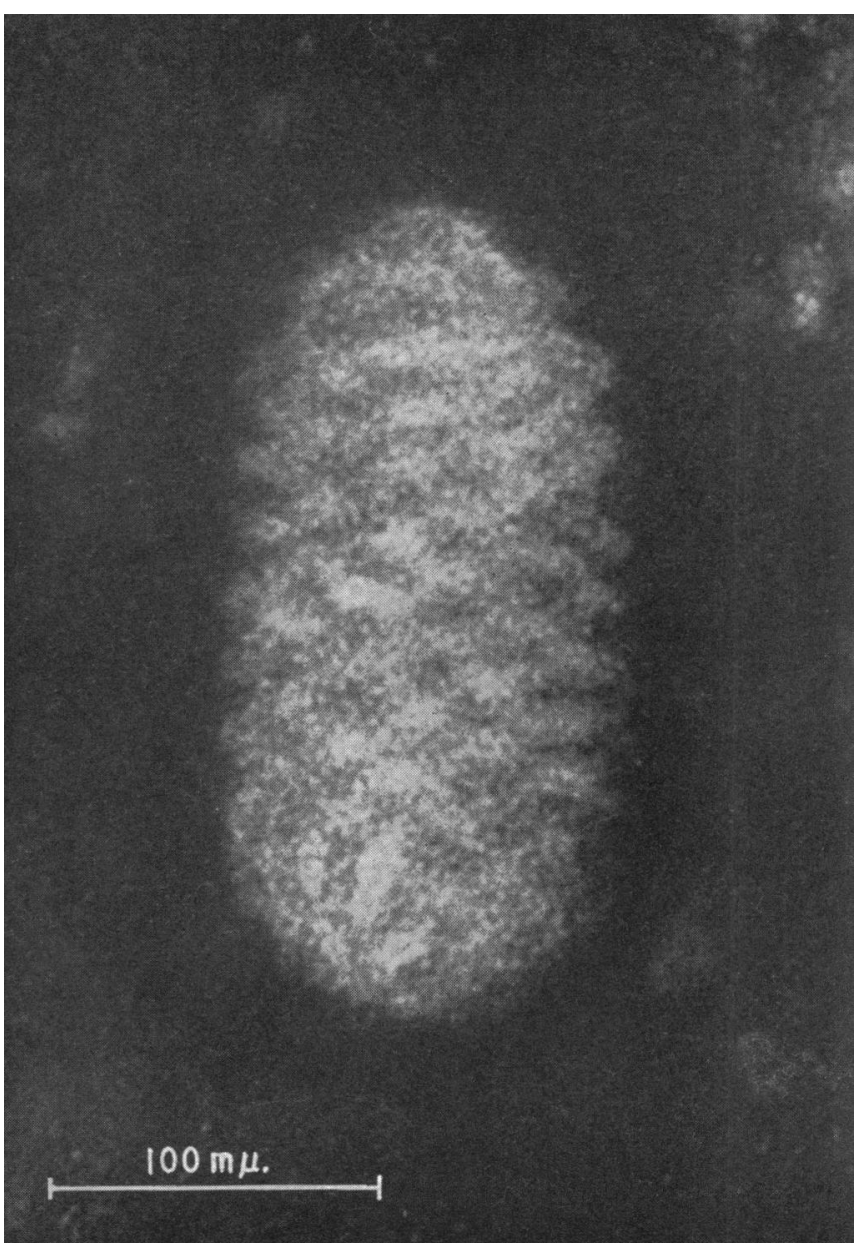

FIG. 2.-Orf virus from crust on animal lesion. $(\times 330,000$. 